\title{
Stainless steel manual metal arc welding fumes in rats
}

\author{
PIRKKO-LIISA KALLIOMÄKI, ${ }^{1}$ EEVA LAKOMAA,${ }^{2} \mathrm{~K}$ KALLIOMÄKI,${ }^{3} \mathrm{M}$ KIILUNEN,${ }^{1} \mathrm{R}$ \\ KIVELÄ, ${ }^{3}$ AND V VAARANEN ${ }^{1}$
}

From the Institute of Occupational Health, ${ }^{1}$ Helsinki, the Technical Research Center of Finland, ${ }^{2}$ Helsinki, and the University of Oulu, ${ }^{3}$ Oulu, Finland

ABSTRACT Forty two male Wistar rats were exposed to manual metal arc (MMA) stainless steel (SS) welding fumes generated by an automatic welding device for "nose-only" exposure. The exposure simulated an actual MMA/SS welding environment as closely as possible. For the retention study, the duration of exposure was one hour per workday for one, two, three, or four weeks and for the clearance study four weeks. The retention and clearance of the chromium, nickel, and iron found in MMA/SS welding fumes in the rats' lungs were studied as was the distribution of the metals to other organs. Instrumental neutron activation analysis (INAA) was used for the multi-element chemical activation analyses. The concentrations of chromium and nickel in the blood and the urine were determined by atomic absorption method (AAS). The retention of exogenous iron was determined by a magnetic measuring method. The results indicated that the lungs were the target organs of soluble hexavalent chromates. The half times of lung clearance for $\mathrm{Cr}, \mathrm{Ni}$, and $\mathrm{Fe}$ were $40 \pm 4 \mathrm{~d}, 20 \pm 2 \mathrm{~d}$, and $50 \pm 10 \mathrm{~d}$. When the lung clearance curves are compared, the half times of $\mathrm{Cr}$ and $\mathrm{Fe}$ lung clearance are similar but nickel disappears faster. The distribution and clearance patterns of chromium to other organs differ from those obtained after single intravenous or intratracheal injections of alkaline chromates.

Alloyed steels resistant to corrosion have replaced non-alloyed steels in many applications during the past decade and hence more chromium and nickel compounds are now found in metal aerosols at industrial workplaces. For instance, stainless steel welding fumes contain both chromium compounds and nickel compounds. The characterisation of manual metal arc (MMA) stainless steel (SS) welding fumes has recently been given much attention ${ }^{1-5}$ (S Kimura et al, paper presented at AES 60th annual meeting, Detroit, April 1979). The total concentration of chromium in MMA/SS welding fumes varies between $3 \%$ and $10 \%$ : water soluble hexavalent alkaline chromates $\left(\mathrm{CaCrO}_{4}, \mathrm{~K}_{2} \mathrm{Cr}_{2} \mathrm{O}_{7}\right)$ comprise $60-95 \%$ of the total concentration of chromium $^{1-5}$ (S Kimura et al, 1979).

The concentration of nickel in MMA/SS welding fumes varies from approximately $0.5 \%$ to $1 \%$. It has been assumed that the fume particles of iron oxide contain an alloyed element of nickel in a poorly water soluble form. ${ }^{145}$

The presence of water soluble hexavalent chromium in MMA/SS welding fumes has led scien-

Received 4 January 1982

Accepted 1 March 1982 tists to estimate the exposure of MMA/SS welders to chromium. The determination of the concentration of chromium in the urine has been used to obtain an estimation of the individual's exposure. ${ }^{6-8}$ The composition of MMA/SS welding fumes and the structure of the chromium compounds and the nickel compounds are complicated, however, and the biological kinetics of the different inorganic components of MMA/SS welding fumes are not known.

The kinetic models of some chromium compounds have been studied, mainly after intravenous or parenteral administration. ${ }^{9-11}$ Chromium compounds differ in their organ distribution and excretion; the difference depends on the valence of the chromium $(\mathrm{Cr})$ found in the compound. The hexavalent form of $\mathrm{Cr}$ is taken up by various organs including the red blood cells; the trivalent form of $\mathrm{Cr}$ is bound in plasma. Within the organism the hexavalent form of $\mathrm{Cr}$ is relatively rapidly reduced to the trivalent form.

The fate of $\mathrm{Cr}$ compounds in the tissues after inhalation has received little attention, even though the respiratory tract is the most important route of occupational exposure. Baetjer et al $^{12}$ reported the lung clearance and the distribution patterns of $\mathrm{Cr}$ in guinea pigs after intratracheal injection. 
Some rat studies have been published about the distribution of the metallic components of different types of welding fumes inhaled by the rats. ${ }^{13-15}$

We have studied the lung retention and lung clearance of the $\mathrm{Cr}$, nickel $(\mathrm{Ni})$, and iron $(\mathrm{Fe})$ found in MMA/SS welding fumes in the rat and the distribution of $\mathrm{Cr}, \mathrm{Ni}$, and $\mathrm{Fe}$ from the lungs to other organs in the rat. The exposure to welding fumes closely simulated the exposure that actually occur in an MMA/SS welding environment.

\section{Materials and methods}

Forty two male Wistar rats $(300 \pm 15 \mathrm{~g})$ were exposed to MMA/SS welding fumes. The rats, which were in good health, were free of respiratory infections. Their feed consisted of commercial rodent chow (Ewas, Astra-Ewas) and tap water ad libitum. The rats were divided into four groups for the study of fume retention and into nine groups for the study of fume clearance. For the retention study, the duration of exposure was one hour per workday for one, two, three, or four weeks and for the clearance study four weeks. The rats of the retention study were decapitated 24 hours after the last exposure. The rats of the clearance group were decapitated one, three, or eight hours, or one, four, eight, 14, 28, 56, or 106 days after the last exposure. Two controls were decapitated on each occasion.

The lungs, kidneys, liver, spleen, and brain were set aside for instrumental neutron activation analysis
(INAA). Contamination was avoided by using prewashed plastic cups, and polyethylene bags and capsules were used to remove and store the organs. The samples were quickly rinsed with deionised water so that blood and airborne particles would be removed from their surfaces. All plastic ware was washed in $2 \mathrm{~N} \mathrm{HNO}_{3}$ EDTA $(6 \mathrm{~g} / \mathrm{l})$ and rinsed with deionised water before use. The blood samples were bled into dry heparinised tubes. Instrumental neutron activation analysis was used to obtain multi-element chemical analysis of the lungs, kidneys, liver, spleen, and brain. The determinations of the concentrations of $\mathrm{Cr}$ and $\mathrm{Ni}$ in the blood and in the urine were carried out by atomic absorption (AAS). The retention of exogenous iron $\left(\mathrm{Fe}_{\mathrm{ex}}\right)$ was determined by a magnetic measuring method. ${ }^{16-17}$

\section{SYSTEM OF EXPOSURE}

Figure 1 shows the exposure chamber developed for use in experiments on exposure to different metal aerosols. The volume of the chamber is $71 \mathrm{l}$. The chamber is fitted with sockets for 57 removable transparent rat holders for "nose-only" exposure. The fume was generated by an automatic arc welder developed for this particular purpose. A portion of the fume was isokinetically sampled and diluted into the exposure chamber. The welded material was stainless steel (AISI 304), and rutile electrodes (Esab OK 63.30 $4 \mathrm{~mm}$ in diameter) were used. The total mass concentration of the fume was $43 \mathrm{mg} / \mathrm{m}^{3}$. On average, the fume contained $3.7 \% \mathrm{Fe}, 3.6 \% \mathrm{Cr}$,



Fig 1 Exposure system for automatic arc welding with coated electrode. 
$0.4 \% \mathrm{Ni}$, and $0.002 \% \mathrm{Co}$. Throughout the exposure period, the mass concentration was checked with dust samples collected on Millipore filters (pore size $0.8 \mu \mathrm{m}, 37 \mathrm{~mm}$ in diameter). The chemical composition of the fumes was determined by the instrumental neutron activation method. The welding fume particles, which are originally very small $(0 \cdot 3-0 \cdot 6$ $\mu \mathrm{m})$, tend to form chains several microns in length. ${ }^{1}$

\section{MEASUREMENT OF EXOGENOUS IRON BY THE MAGNETIC TECHNIQUE}

Stainless steel welding fumes contain iron, some of which is in magnetic form (magnetite). Because endogenous lung iron is non-magnetic, the amount of exogenous lung iron may be measured by the magnetic measuring technique. ${ }^{16}{ }^{17}$ The iron content of the examined lungs was measured with a SQUID magnetometer in a magnetically shielded room located at Helsinki University of Technology. The sensitivity of the measurements is $0.3 \mathrm{nAm}^{2}$, which corresponds to $0.1 \mu \mathrm{g}$ of magnetite or $0.3 \mu \mathrm{g}$ of fume iron.

\section{ATOMIC ABSORPTION SPECTROMETRIC}

\section{DETERMINATION}

The blood analyses were done by electrothermal atomic absorption spectrometry (Perkin-Elmer 4000 with HGA 400), and the samples were injected manually into graphite tubes. The ramp heating programme was used for the determinations of both chromium and nickel. The atomising temperature was $2500^{\circ} \mathrm{C}$.

The blood samples were diluted with nitric acid (1 part blood: 5 parts $\mathrm{HNO}_{3}$ ) to reach $\mathrm{pH} 2$. The reference samples were prepared from the blood samples of unexposed rats. Chromium was analysed directly from the dilution, but the samples were first centrifuged for the analysis of nickel. The method for the analysis of $\mathrm{Cr}$ was similar to the method described by Tola et al. ${ }^{7}$

All the nickel seemed to remain in the supernatant; burnt blood samples yielded the same results as the direct acid dilution. The precision of the method, which was calculated from 10 consecutive injections of the same dilution, was $4 \%$ for $\mathrm{Cr}$ and $2 \%$ for $\mathrm{Ni}$.

\section{NEUTRON ACTIVATION ANALYSIS}

The organ samples were lyophilised, and $60-160 \mathrm{mg}$ of dried sample was sealed into a quartz ampoule, which was then irradiated for 30 hours together with a liquid standard and National Bureau of Standards reference materials (SRM 1577 and 1571). The irradiation took place in the neutron flux $\left(10^{13} \mathrm{n}\right.$ $\mathrm{cm}^{-2} \mathrm{~s}^{-1}$ ) of a Triga Mark II reactor. After a period of decay lasting three to six weeks, the gammaactivities were measured for three hours by an Ortec
$25 \% \mathrm{Ge}(\mathrm{Li})$ detector (resolution $2 \cdot 1 \mathrm{keV}$ at 1335.5 $\mathrm{keV}$ ) connected to an automatic gammaspectrometer (Nokia LP 4900). Chromium, iron, cobalt, zinc, selenium, and rubidium were determined quantitatively. The reliability of the analysis was checked by analysing reference material of National Bureau of Standards bovine liver or orchard leaves (SRM 1577 and 1571). According to the results obtained with the reference materials, the determinations were reliable throughout the study.

The instrumental neutron activation method detection limit was 1.1 for $\mathrm{Cr}, 16$ for $\mathrm{Fe}$, and 0.7 for $\mathrm{Ni}$, all expressed as $\mu \mathrm{g} / \mathrm{g}$ dry weight.

\section{Results}

LUNG RETENTION AND CLEARANCE

The retention and clearance patterns of $\mathrm{Cr}, \mathrm{Ni}$, and $\mathrm{Fe}_{e x}$ in the lungs are shown in figs $2 \mathrm{a}$ and $2 \mathrm{~b}$. A linear relationship was observed between the duration of exposure and the concentrations of $\mathrm{Cr}, \mathrm{Ni}$, and $\mathrm{Fe}_{\mathrm{ex}}$ in the lungs. The average concentrations of $\mathrm{Cr}$ in the lungs 24 hours after the maximum expos-
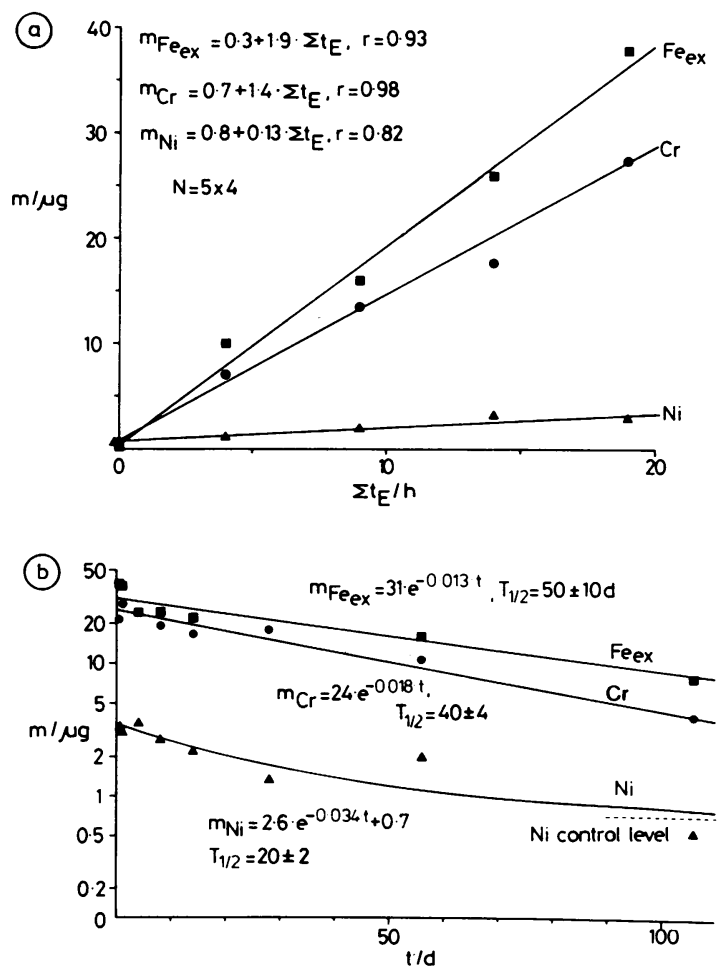

Fig 2 (a) Retention pattern and (b) clearance pattern of chromium ( $\mathrm{Cr})$, nickel $(\mathrm{Ni})$, and exogenous iron $\left(\mathrm{Fe}_{\mathrm{ex}}\right)$ in the lungs of rats exposed to MMA/SS welding fumes. 
ure $(19 \mathrm{~h})$ was $57 \mathrm{ppm}$, which corresponds to a total lung $\mathrm{Cr}$ content of $27 \mu \mathrm{g}$. Typical concentrations for $\mathrm{Ni}$ and $\mathrm{Fe}_{\mathrm{ex}}$ were $6.7 \mathrm{ppm}$ and $76 \mathrm{ppm}$, respectively; thus the $\mathrm{Ni}$ and $\mathrm{Fe}_{\mathrm{ex}}$ contents of the lungs were 3.3 $\mu \mathrm{g}$ and $36 \mu \mathrm{g}$.

The biological half times of lung clearance (single exponential function fit) were $40 \pm 4 \mathrm{~d}$ for $\mathrm{Cr}, 20 \pm 2$ $\mathrm{d}$ for $\mathrm{Ni}$, and $50 \pm 10 \mathrm{~d}$ for $\mathrm{Fe}_{\mathrm{ex}}$ (fig 2b). The lung clearance was faster in the beginning of the clearance period, but a multiexponential clearance model could not be applied because the number of points was limited. When the lung clearance curves are compared, the half times of the lung clearance of $\mathrm{Cr}$ and $\mathrm{Fe}_{\mathrm{ex}}$ are similar, whereas $\mathrm{Ni}$ disappears faster.

\section{CHROMIUM AND NICKEL IN THE BLOOD AND THE} URINE

The concentration of $\mathrm{Cr}$ in the whole blood was constant $(0.53 \pm 0.05 \mu \mathrm{mol} / \mathrm{l})$ during the period of exposure, but it decreased rapidly $\left(\mathrm{T}_{1 / 2}=6.0 \pm 0.4 \mathrm{~d}\right)$ after the exposure ceased (fig 3 ). The estimated maximum $\mathrm{Cr}$ content of the blood was $0.5 \mu \mathrm{g}$. The concentration of $\mathrm{Ni}$ in the blood was below the detection limit $(0.05 \mu \mathrm{mol} / \mathrm{l})$. The amount of $\mathrm{Fe}_{\mathrm{ex}}$ in the blood was less that $1 \mu \mathrm{g}$.

Because it proved difficult to collect the urine samples without contamination, the analyses of $\mathrm{Cr}$ and $\mathrm{Ni}$ in the urine were not exact. The urine analyses performed, however, indicated that the immediate concentration of $\mathrm{Cr}$ in the urine after any period of exposure was $1 \cdot 1 \pm 0.4 \mu \mathrm{mol} / \mathrm{l}$. The urinary concentration of $\mathrm{Ni}$ was $0 \cdot 31 \pm 0 \cdot 10 \mu \mathrm{mol} / \mathrm{l}$.

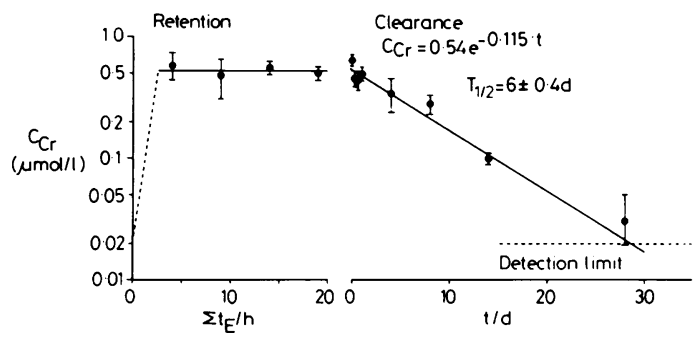

Fig 3 Concentration of chromium ( $\mathrm{Cr}$ ) in blood as a function of duration of exposure and duration of clearance.

The diurnal excretion rate into the urine was approximately $0.23 \mu \mathrm{g} / \mathrm{d}$ for $\mathrm{Cr}$ and $0.07 \mu \mathrm{g} / \mathrm{d}$ for $\mathrm{Ni}$. When the concentrations of $\mathrm{Cr}$ and $\mathrm{Ni}$ within the exposure chamber are compared, it can be seen that $\mathrm{Ni}$ is excreted into the urine faster than $\mathrm{Cr}$.

The estimated amount of $\mathrm{Cr}$ excreted into the urine throughout the total period of exposure was 6 $\mu \mathrm{g}$. The corresponding amount for $\mathrm{Ni}$ was $1.8 \mu \mathrm{g}$.

\section{CONCENTRATIONS OF CHROMIUM AND NICKEL}

IN OTHER ORGANS

In the liver the concentration of $\mathrm{Cr}$ did not increase significantly during the first week of exposure. The concentration of $\mathrm{Cr}$ in the liver then began to increase, and it reached the maximum level about three weeks after the last exposure. The concentration of $\mathrm{Cr}$ in the liver returned to the level of the controls in two months (table 1). The maximum content of $\mathrm{Cr}$ in the liver was approximately $3 \mu \mathrm{g}$.

Table 1 Mean values of the concentrations of $\mathrm{Cr}$ and $\mathrm{Ni}$ in different rat organs as a function of cumulative duration of exposure/clearance after the termination of exposure. The concentrations are expressed as $\mu \mathrm{g} / \mathrm{g}$ dry weight

\begin{tabular}{|c|c|c|c|}
\hline \multirow{2}{*}{$\begin{array}{l}\text { Cumulative duration } \\
\text { of exposure }(h)\end{array}$} & \multicolumn{3}{|c|}{ Concentration of chromium $\pm S D(\mu g / g)$} \\
\hline & Liver & Kidneys & Stomach \\
\hline $\begin{array}{r}4 \\
9 \\
14 \\
19\end{array}$ & $\begin{array}{l}0 \cdot 19 \pm 0 \cdot 12 \\
0 \cdot 0 \\
0 \cdot 08 \\
0 \cdot 3 \pm 0 \cdot 4\end{array}$ & $\begin{array}{l}0 \cdot 45 \pm 0.33 \\
0 \cdot 32 \pm 0 \cdot 15 \\
0 \cdot 69 \pm 0 \cdot 10 \\
0 \cdot 45 \pm 0 \cdot 19\end{array}$ & $\begin{array}{l}1 \cdot 08 \pm 0 \cdot 26 \\
1 \cdot 54 \pm 0.30 \\
1 \cdot 1 \pm 0 \cdot 6 \\
0.9 \pm 0.3\end{array}$ \\
\hline Controls $(n=15)$ & $0 \cdot 16 \pm 0 \cdot 17$ & $0 \cdot 16 \pm 0 \cdot 18$ & $0.75 \pm 0.28$ \\
\hline $\begin{array}{l}\text { Duration of clearanc } \\
0 \cdot 04 \\
0 \cdot 13 \\
0 \cdot 33 \\
1 \\
4 \\
8 \\
14 \\
28 \\
56 \\
106\end{array}$ & $\begin{array}{l}0 \cdot 11 \pm 0 \cdot 11 \\
0.29 \pm 0 \cdot 25 \\
0 \cdot 43 \pm 0 \cdot 26 \\
0 \cdot 31 \pm 0 \cdot 38 \\
0 \cdot 39 \pm 0.43 \\
0.32 \pm 0 \cdot 12 \\
0 \cdot 83 \pm 0.52 \\
0 \cdot 80 \pm 0.39 \\
0 \cdot 15 \pm 0 \cdot 12 \\
0.07 \pm 0.05\end{array}$ & $\begin{array}{l}0 \cdot 63 \pm 0.59 \\
0.71 \pm 0 \cdot 13 \\
0 \cdot 50 \pm 0.42 \\
0 \cdot 45 \pm 0 \cdot 19 \\
0 \cdot 82 \pm 0 \cdot 34 \\
0 \cdot 63 \pm 0.48 \\
0 \cdot 62 \pm 0 \cdot 41 \\
0 \cdot 14 \pm 0 \cdot 05 \\
0 \cdot 30 \pm 0 \cdot 02 \\
-\end{array}$ & $\begin{array}{l}1 \cdot 3 \pm 0 \cdot 6 \\
1 \cdot 3 \pm 0 \cdot 7 \\
1 \cdot 1 \pm 0 \cdot 4 \\
0 \cdot 9 \pm 0 \cdot 3 \\
0 \cdot 7 \pm 0 \cdot 12 \\
0 \cdot 8 \pm 0 \cdot 4 \\
0 \cdot 5 \pm 0 \cdot 14 \\
2 \cdot 0 \\
1 \cdot 1 \pm 0 \cdot 3 \\
-\end{array}$ \\
\hline 106 & \multicolumn{3}{|c|}{ Concentration of nickel $\pm \mathrm{SD}(\mu \mathrm{g} / \mathrm{g})$} \\
\hline $\begin{array}{l}\text { Controls } \\
\text { Exposed rats }\end{array}$ & $\begin{array}{l}1 \cdot 0 \pm 0 \cdot 9 \\
\text { Not significantly raised }\end{array}$ & $0 \cdot 5 \pm 0 \cdot 3$ & $1 \cdot 6 \pm 0 \cdot 7$ \\
\hline
\end{tabular}






Fig 4 Chromium ( $\mathrm{Cr}$ ) content of spleen as a function of duration of exposure and duration of clearance.

In the kidneys the concentration of $\mathrm{Cr}$ increased to its maximum level during the first week of exposure, it then decreased to the level of the controls about 30 days after the last exposure (table 1). The maximum content of $\mathrm{Cr}$ in the kidneys was approximately $0.6 \mu \mathrm{g}$.

In the spleen the concentration of $\mathrm{Cr}$ increased during the period of exposure, and it continued to increase for two months after the termination of exposure. This continuing increase indicates that $\mathrm{Cr}$ from the red blood cells accumulates in the spleen (fig 4). The maximum content of $\mathrm{Cr}$ in the spleen was $0 \cdot 12 \mu \mathrm{g}$.

In the stomach the concentration of $\mathrm{Cr}$ increased slightly during the exposure, but no clear accumulative trend could be discerned (table 1).

The concentrations of $\mathrm{Ni}$ in the liver, kidneys, and spleen corresponded to concentration of the controls. No $\mathrm{Fe}_{\mathrm{ex}}$ could be detected in the organs examined.

In the brain the concentrations of $\mathrm{Cr}, \mathrm{Ni}$, and $\mathrm{Fe}_{\mathrm{ex}}$ did not differ from the corresponding values in the control animals.

\section{Discussion}

The data provided by this study are relevant to human exposure to MMA/SS welding fumes and the subsequent distribution of metals such as chromium and nickel to organ tissues. The exposure conditions simulated the actual MMA/SS welding environment as closely as possible.

If one assumes that the ventilation rate of rats is $0 \cdot 1 \mathrm{l} / \mathrm{h}$ then the rats in our study inhaled a maximum of $164 \mu \mathrm{g}$ of $\mathrm{Cr}, 170 \mu \mathrm{g}$ of $\mathrm{Fe}$, and $18 \mu \mathrm{g}$ of nickel. If one estimates that the rats' lungs retained $30 \%$ of the contaminants contained in the welding fumes inhaled the total theoretical retentions are $50 \mu \mathrm{g}$ for $\mathrm{Cr}, 55 \mu \mathrm{g}$ for $\mathrm{Fe}$, and $5.6 \mu \mathrm{g}$ for $\mathrm{Ni}$ (table 2).

The maximum lung content of $\mathrm{Cr}$ measured was
$27 \mu \mathrm{g}$. The corresponding content was $38 \mu \mathrm{g}$ for $\mathrm{Fe}$ and $3.4 \mu \mathrm{g}$ for Ni (table 2). The results indicate that the lungs are the main target organ of the $\mathrm{Cr}$ compounds found in MMA/SS welding fumes. The water soluble hexavalent alkaline chromates found in welding fumes are therefore chemically transformed into insoluble $\mathrm{Cr}$ compounds in the respiratory tract.

When the lung clearance curves were compared, the half times of $\mathrm{Cr}$ and $\mathrm{Fe}_{\mathrm{ex}}$ lung clearance were similar, but nickel disappeared faster from the lungs. The excretion of $\mathrm{Ni}$ into the urine was also faster than that of $\mathrm{Cr}$, even though the $\mathrm{Ni}$ compounds found in MMA/SS welding fumes have been assumed to be in a poorly water soluble form. The half time of $\mathrm{K}_{2} \mathrm{Cr}_{2} \mathrm{O}_{7}$ after intratracheal injection into guinea pigs was $40 \pm 5 \mathrm{~d} .{ }^{12}$ Thus the lung clearance pattern of the $\mathrm{Cr}$ compounds found in MMA/ SS welding fumes resembles that of pure alkaline chromates. After the rats had been given $\mathrm{Na}_{2}{ }^{51} \mathrm{CrO}_{4}$ intravenously, the lung retention and clearance patterns differed from those of our study. ${ }^{10}$ The $\mathrm{Cr}$ content of the lungs measured one hour after intravenous injection was about $15 \%$ of the total single chromate dose, and $\mathrm{Cr}$ was eliminated from the lungs very rapidly (the half time of lung clearance was about $3 \mathrm{~d}$ ).

In the whole blood the content of $\mathrm{Cr}$ was constant at $0.5 \mu \mathrm{g}$ throughout the entire exposure period, and the half time of $\mathrm{Cr}$ clearance was $6 \mathrm{~d}$. One hour after intravenous injection of chromate into rats, the accumulation of $\mathrm{Cr}$ measured in the whole blood was high, about $25 \%$ of the total injected dose, and the half time of $\mathrm{Cr}$ clearance was about $13 \mathrm{~d}$. Conversely, the content of $\mathrm{Cr}$ in the plasma at the same point in time was low, about $7 \%$ of the injected dose, and $\mathrm{Cr}$ was rapidly eliminated from the plasma $\left(\mathrm{T}_{1 / 2}=2 \mathrm{~d}\right) \cdot{ }^{10}$ Thus the clearance rate of $\mathrm{Cr}$ from the whole blood after the long term inhalation of the $\mathrm{Cr}$

Table 2 Retention, clearance, and distribution of chromium $(\mathrm{Cr})$, nickel $(\mathrm{Ni})$, and iron $(\mathrm{Fe})$ compounds found in MMA/SS welding fumes, in rats




compounds found in MMAVSS welding fumes was faster than that which occurred after the single intravenous injection of pure chromate. Further inhalation studies are necessary so that the distribution of $\mathrm{Cr}$ between the plasma and the blood cells can be discerned.

In the liver the concentration of $\mathrm{Cr}$ began to increase three weeks after the initial exposure. The maximum content $(3 \mu \mathrm{g})$ was reached three to four weeks after the last exposure. The content of $\mathrm{Cr}$ decreased to the level of controls two months after the termination of exposure. After the single intravenous injection of chromate, the concentration of $\mathrm{Cr}$ in the liver increased immediately to a high level and was thereafter eliminated rapidly $\left(T_{1 / 2}=5 \mathrm{~d}\right) .{ }^{10}$ It may be assumed, therefore, that the mechanism of $\mathrm{Cr}$ deposition in the liver differs in these two studies. Our results suggest that the concentration of $\mathrm{Cr}$ measured in the liver after inhalation is mainly due to $\mathrm{Cr}$ that has been translocated from the lungs, whereas after the single intravenous injection of $\mathrm{Cr}$ into the lungs $\mathrm{Cr}$ was transported either by plasma proteins or by red blood cells.

In the kidneys also the accumulation and the clearance patterns of $\mathrm{Cr}$ differed from those observed after a single intravenous injection. ${ }^{10}$ In our study the content of $\mathrm{Cr}$ in the kidneys reached its maximum level $(0.6 \mu \mathrm{g})$ during the first week of exposure. This relatively constant level, which was maintained until two weeks after the termination of exposure, then decreased to the level of the controls in two weeks. The total amounts of $\mathrm{Cr}$ and $\mathrm{Ni}$ excreted into the urine during the exposure period were estimated at $6 \mu \mathrm{g}$ and $1.8 \mu \mathrm{g}$, respectively. Further investigations are necessary to obtain a more exact understanding of the excretion patterns of $\mathrm{Cr}$ and $\mathrm{Ni}$.

In the spleen the content of $\mathrm{Cr}$ continued to increase after the termination of exposure (the max-

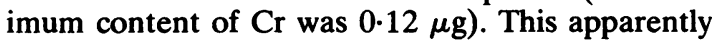
indicates that $\mathrm{Cr}$ liberated from red blood cells accumulates in the spleen. A similar tendency for chromates to accumulate in the spleen was observed after the intratracheal injection of $\mathrm{K}_{2} \mathrm{Cr}_{2} \mathrm{O}_{4}$ into guinea pigs ${ }^{12}$ as well as after the intravenous administration of $\mathrm{Na}_{2} \mathrm{CrO}_{4}$ into rats. ${ }^{10}$

Our results have partially shown the kinetics of the most interesting compounds found in MMA/SS welding fumes that occur in some organs of the rat. It appears that the kinetics of both $\mathrm{Cr}$ compounds and $\mathrm{Ni}$ compounds depend on the route of intake, but a more thorough understanding of the toxicokinetics of $\mathrm{Cr}$ compounds and $\mathrm{Ni}$ compounds in the organism may be attained only after further research. The relatively low concentration of $\mathrm{Ni}$ compounds in MMA/SS welding fumes and the detection limit of the analytical methods of analysis used prevented us from acquiring a precise understanding of the kinetics of $\mathrm{Ni}$ in various organs.

\section{References}

' Stern RM. A chemical, physical and biological assay of welding fumes. (Publication 77.05.) Copenhagen: Danish Welding Institute, 1977

${ }^{2}$ Ulfvarsson U, Hallne U, Bellander T, Sjögren B, Swensson Å. Arbetsmiljöproblem vid svetsning. Del 5. Svetsning $i$ rostfritt stål med metallbågsvetsning och gasbågsvetsning. I Kartläggning av lufiföroreningar II. Medicinsk undersökning av svetsare. Stockholm: Arbete och Hälsa, 1978:8.

${ }^{3}$ Koshi K. Effects of fume particles from stainless steel welding on sister chromatic exchanges and chromosome aberrations in cultured Chinese hamster cells. Ind Health 1979;17:39-49.

${ }^{4}$ Lautner GM, Carver JC, Konzen RB. Measurement of chromium VI and chromium III in stainless steel welding fumes with electron spectroscopy for chemical analysis and neutron activation analysis. Am Ind Hyg Assoc J 1979;39:651-9.

${ }^{5}$ Malmqvist K, Johansson G, Bohgard M, Akselsson R. Lufiföroreningar vid svetsning; Karakterisering av svetsrök. Lund: Institutionen för kärnfysik vid Lunds Tekniska Högskola, 1980. (Slutrapport för del 2 av ASF-projekt Dnr 74/198.)

- Gylseth B, Gundersen N, Langård S. Evaluation of chromium exposure based on a simplified method for urinary chromium determination. Scand J Work Environ Health 1977;3:28-31.

' Tola S, Kilpiö J, Virtamo M, Haapa K. Urinary chromium as an indicator of the exposure of welders to chromium. Scand $J$ Work Environ Health 1977;3:192-202.

- Mutti A, Cavatorta A, Pedroni C, Borgi A, Giaroli C, Franchini I. The role of chromium accumulation in the relationship between airborne and urinary chromium in welders. Int Arch Occup Environ Health 1980;43:85-91.

${ }^{9}$ Hopkins LL. Distribution in the rat of physiological amounts of injected $\mathrm{Cr}^{51}$ (III) with time. Am J Physiol 1965;209:731-5.

${ }^{10}$ Langård S. The time-related subcellular distribution of chromium in the rat liver cell after intravenous administration of $\mathrm{Na}_{2} \mathrm{CrO}_{4}$. Biological Trace Element Research 1979;1:45-54.

"Mertz W, Roginski EE, Reba RC. Biological activity and fate of trace quantities of intravenous chromium (III) in the rat. Am J Physiol 1965;209:489-94.

12 Baetjer AM, Damron C, Budacz V. The distribution and retention of chromium in men and animals. AMA Archives of Industrial Health 1959;2:136-50.

${ }^{13}$ Hewitt PJ, Hicks R. Neutron activation analysis of blood and body tissue from rats exposed to welding fumes. Nuclear activation techniques in the life sciences 1972. Vienna: International Atomic Energy Authority 1972:219-32.

${ }^{14}$ Hewitt PJ, Hicks R. An investigation of the effects of inhaled welding fume in the rat. Ann Occup Hyg 1977;16/B:213-21.

is Al-Shamma KJ, Hewitt PJ, Hicks R. Distribution of some metallic components of inhaled MIG welding fume in the rat. Nuclear activation techniques in the life sciences 1978. Vienna: International Atomic Energy Authority, 1979:657-66.

${ }^{16}$ Kalliomäki K, Kalliomäki P-L, Kelhä V, Vaaranen V. Instrumentation for measuring the magnetic lung contamination of steel welders. Ann Occup Hyg 1980;23:175-84.

17 Kalliomäki K, Aittoniemi K, Kalliomäki P-L, Moilanen M. Measurement of lung-retained contaminants in vivo among workers exposed to metal aerosols. Am Ind Hyg Assoc J 1981;42:234-9. 